\title{
CHEMICAL MODIFICATIONS IN THE TETRACYCLINE SERIES
}

\author{
U. VALCAVI \\ Istituto Biochimico Italiano, Via G. Lorenzini, 2 Milano, Italy \\ and Istituto Chimica Organica dell'Università di Milano, \\ Via Saldini, 50, Milano, Italy \\ A. Brandt, G. B. Corsi, F. Minoja and G. Pascucci \\ IBI SUD, Research Laboratory, Via di Fossignano, 2 Aprilia (Latina), Italy
}

(Received for publication July 24, 1980)

\begin{abstract}
New tetracycline analogs modified at position 5, 6 and 2 were synthetized. The 5-deoxy5-oxo-derivatives, $2 \mathrm{a}$ and $\mathbf{3 a}$, were obtained by DMSO/acetic anhydride oxidation of doxycycline (2) and methacycline (3), respectively; the 6-demethyl-6-hydroxymethyl-6-alpha-hydroxyoxytetracycline (3b) by methacycline oxidation with the $\mathrm{KClO}_{3} / \mathrm{OsO}_{4}$ system and the 6-hydroxyanhydrooxytetracycline (4) treating $\mathbf{3 b}$ with periodic acid. The 2-ethoxycarbonyl-2-decarboxamidodoxycycline (2b), was synthetized by treating doxycycline nitrile (2c) with $\mathrm{EtOH}$ and anhydrous $\mathrm{HCl}, 2$-thiocarboxamide-2-decarboxamidodoxycycline (2d) by reaction of doxycycline with $\mathrm{P}_{2} \mathrm{~S}_{5}$ in dioxane and 2-aminomethyl-2-decarboxamidodoxycycline (2e) by RANEY-Nickel reduction of $\mathbf{2 d}$. All the synthetized compounds proved to be almost inactive on agar plates both on Gram-positive and Gram-negative bacteria.
\end{abstract}

Tetracycline antibiotics continue also today to play an important role in human and veterinary medicine and in animal nutrition.

The greatest success in the development of new active tetracycline has been up to now obtained by modifications at the position 6 . The position 5 also seems not very critical for antimicrobial activity influencing mainly the pharmacokinetics properties ${ }^{1,2}$.

During a research program aimed at finding new and possibly clinically useful tetracycline derivatives, our synthetic efforts followed mainly two routes: on one side we took up the synthesis of some new derivatives (compounds $2 \mathbf{a}, 3 \mathbf{3}, 3 \mathbf{b}, 4)$ modified at position 5 and 6 starting from the easily available, acid stable doxycycline (2) and methacycline (3) and, on the other side, we paid also our attention to modifications at position 2 .

From structure-activity relationships studies it is in fact shown that only a carbonyl substituent at position 2 and not the whole carboxamide group is essential for maintenance of activity: the nitrile (1a) ${ }^{3)}$ has no activity but derivatives bearing at the 2 positions an aldehyde $(\mathbf{1 b})^{4)}$, aldimine $(\mathbf{1 c})^{5)}$ or acetyl $(\mathbf{1 d})^{6)}$ group retain a certain degree of antimicrobial activity.

It seemed therefore interesting ${ }^{7)}$, in order to define the role of the $\mathrm{C}-2$ carboxamidic group, to synthetize new C-2 derivatives, namely the 2ethoxycarbonyl (2b), the 2-thiocarboxamide (2d), the 2-aminomethyl (2e) and the 2-N-methylaminomethyl doxycycline.

Fig. 1.

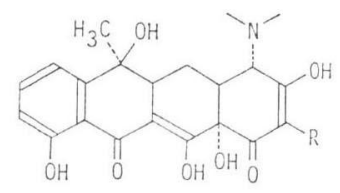

$1 \mathrm{R}=\mathrm{CONH}_{2}$ (tetracycline)

1a $\mathrm{R}=\mathrm{C} \equiv \mathrm{N}$

1b $\quad \mathrm{R}=\mathrm{CHO}$

1c $\mathrm{R}=\mathrm{CH}=\mathrm{NOH}$

1d $\mathrm{R}=\mathrm{COCH}_{3}$ 


\section{Results and Discussion}

Modifications at C5

Pursuing the goal of obtaining new, previously unknown derivatives, we studied the oxidation of the 5-alpha-hydroxyl group to 5-keto of the two widely used semisynthetic tetracyclines, doxycycline (2) and methacycline (3). While the oxidation of $\mathbf{2}$ or $\mathbf{3}$ with chromium and manganese compounds led only to degradated products, reaction with dimethylsulfoxide (DMSO) and acetic anhydride gave mainly a product to which was assigned the structure $\mathbf{2 a}$ or $3 \mathbf{a}$ respectively.

Fig. 2.

The IR spectrum of these compounds was characterized by a peak at $1740 \mathrm{~cm}^{-1}$ according with a keto group not involved in the keto-enol system. The presence of an acetyl ester group was excluded by the NMR spectrum and also by some preliminary proofs in which the use of acetic anhydride was avoided and the reaction was carried out with DMSO and phosphoric acid giving the same product but in lower yield.

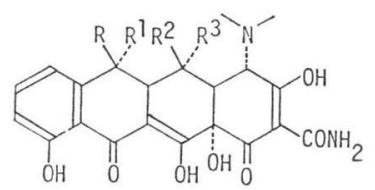

Both compounds $\mathbf{2 a}$ and $\mathbf{3 a}$ proved to be practically inactive when tested for minimal inhibitory concentration on agar plates, using a representative number of Gram-positive and Gram-negative bacterial strains normally used for screening tests.

\section{Modifications at C-6}

Few reactions have been reported on the exocyclic double bond of the methacycline other than, a free-radical mercaptan addition ${ }^{8)}$ and catalytic hydrogenation. ${ }^{9)}$ According to our results, this double bond is very scarcely reactive, for example it has been impossible to epoxidize it without complete degradation of the molecule and it did not react at all with some methylides in anhydrous THF after complete sylilation of the hydroxyl groups. Nevertheless 3 reacts with the oxidizing system $\mathrm{OsO}_{4} /$ $\mathrm{KClO}_{3}$ in $\mathrm{MeOH} / \mathrm{H}_{2} \mathrm{O}$ giving the 6-demethyl-6-hydroxymethyloxytetracycline (3b) in good yield. In the NMR spectrum of $\mathbf{3} \mathbf{b}$ the shift of the $\mathrm{CH}_{2}$ signal from $\delta 5.2$ (in methacycline) to $\delta 3.4$ (assigned to the $\mathrm{CH}_{2} \mathrm{OH}$ ) was diagnostic, nevertheless, it was impossible to assign the stereochemistry of the new asymmetric center only on this basis. Moreover $\mathbf{3 b}$ when treated with refluxing $0.8 \mathrm{~N}$ hydrochloric acid in the usual way ${ }^{10)}$, didn't give the corresponding expected 5a-6-anhydroderivative, probably owing to a cis-correlation between the hydroxy group at $\mathrm{C}_{5}$ and the hydrogen at $\mathrm{C}_{5 \mathrm{a}}$. Also some speculations on molecular models about the side of $\mathrm{OsO}_{4}$ addition were in agreement with an unnatural configuration at $\mathrm{C}_{8}$.

Compound $\mathbf{3 b}$ reacted with periodic acid, in the usual mild conditions used for cleavage of 1,2diols, to give the 6-demethyl-6-hydroxyanhydrooxytetracycline (4) via a labile 6-demethyl-6-oxodoxycycline. The structure of $4^{*}$ was mainly based on the UV spectrum on which the absorption at $274 \mathrm{~nm}$ $(\varepsilon=16,000)$ indicated the A ring unchanged and a second band at $471 \mathrm{~nm}(\varepsilon=7,000)$ was considered diagnostic for the new B-C-D ring system, considering a circa $30 \mathrm{~nm}$ bathochromic shif ${ }^{11)}$ owing to the presence of the para hydroxyl group on the B ring, in comparison with the usual anhydrotetracycline derivative.

* In the same conditions, doxycycline did not react. 
Scheme 1.

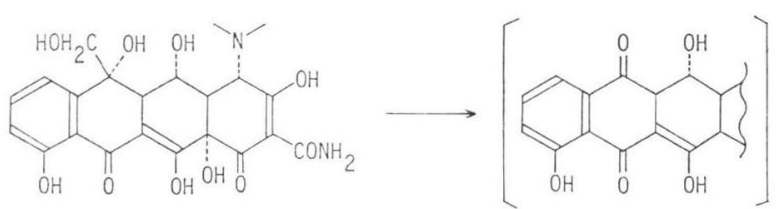

$3 b$

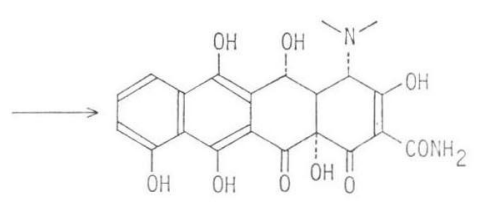

4
Fig. 3.

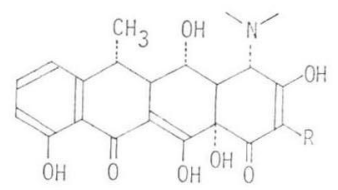

$2 \mathrm{R}=\mathrm{CONH}_{2}$ (doxycycline)

2b $\quad \mathrm{R}=\mathrm{COOEt}$

2c $\mathrm{R}=\mathrm{C} \equiv \mathrm{N}$

2d $\mathrm{R}=\mathrm{CSNH}_{2}$

2e $\mathrm{R}=\mathrm{CH}_{2} \mathrm{NH}_{2}$

2f $\mathrm{R}=\mathrm{CONHCH}_{2} \mathrm{~N}\left(\mathrm{CH}_{3}\right) \mathrm{CH}_{2} \mathrm{Ph}$

Compound $\mathbf{3 b}$, when tested against some bacteria on agar plate (MIC) was shown to be less active than the parent tetracycline while 4 proved to be inactive.

\section{Modifications at $\mathrm{C}-2$}

Doxycycline nitrile (2c), starting material for the 2-ethoxycarbonyl derivative (2b), has been prepared by reaction of doxycycline with dicyclohexylcarbodiimide (DCC) in $\mathrm{MeOH}$ (see Experimental).

Reaction of $2 \mathrm{c}$ with hydrogen chloride in EtOH at reflux gave, after purification, in poor yields, the 2-ethoxycarbonyl-2-decarboxamidodoxycycline (2b). The structure of this compound was assigned on the base of its spectral data: the UV spectrum showed an unchanged doxycycline skeleton, the presence of the ethyl groups was diagnostic in the NMR, and in the IR spectrum the disappearance of the nitrile absorption band and the appearance of new peak at $1740 \mathrm{~cm}^{-1}$, characteristic for an ester group, was clearly evident.

After many inconclusive efforts to obtain the 2-thioamide (2d) by treatment of the nitrile (2c) with $\mathrm{H}_{2} \mathrm{~S}$ or with thioacetamide, we found that the reaction of doxycycline hydrochloride with $\mathrm{P}_{2} \mathrm{~S}_{5}$ in dioxane for 16 hours at room temperature, followed by purification, gave the 2-thiocarboxamido-2-decarboxamido-doxycycline (2d) in good yield.

The structure of $2 \mathrm{~d}$ was confirmed by elemental analysis, spectroscopic evidences and also by some chemical proofs.

So, the doxycycline nitrile (2c) did not react with $\mathrm{P}_{2} \mathrm{~S}_{5}$, that is only the carboxamido group was involved in the reaction, and $2 \mathrm{~d}$ did not react, like doxycycline does, with dicyclohexylcarbodiimide (DCC) in methanol to give the corresponding nitrile derivatives (see Experimental).

The compound ( $\mathbf{2 d}$ ) was also reduced with freshly prepared RANEY-Nickel to give the 2-aminomethyl derivative (2e). Also the structure of $2 \mathrm{e}$ was assigned on the bases of the analytical data (absence of $\mathrm{S}$ in the elemental analysis and UV spectrum unchanged) and chemical reactions (doxycycline did not react in the same conditions).

Nevertheless, $2 \mathrm{e}$ was not very stable, in our opinion owing to a SCHiff intermolecular condensations of the new primary amino group.

A similar attack was also supposed the first step of a more complex rearrangement that has been observed in the attempted synthesis of the $2 \mathrm{~N}$-methylaminomethyl derivative, during the benzyl group hydrogenolysis on $\mathrm{Pt}_{2} \mathrm{O}$ of the compound $2 \mathrm{f}$ obtained by a MANNICH reaction ${ }^{12)}$ among doxycycline, 
formaldehyde and $\mathrm{N}$-methyl-N-benzylamine*. While doxycycline with $\mathrm{Pt}_{2} \mathrm{O}$ under hydrogen at atmospheric pressure did not react for several hours, in the case of $\mathbf{2} \mathbf{f}$ the production near quantitative of toluene was observed (G.C.), but it was impossible to isolate the $2 \mathrm{~N}$-methylaminomethyldoxycycline owing to further reactions of the secondary amino group to give a yellow-orange product not certainly identified on the basis of spectral data.

According to the NMR spectra of all these compounds modified at C-2, the asymmetric centers at $\mathrm{C}_{4}, \mathrm{C}_{4 \mathrm{a}}, \mathrm{C}_{5}, \mathrm{C}_{5 \mathrm{a}}, \mathrm{C}_{8}, \mathrm{C}_{12 \mathrm{a}}$ remained unchanged during these reactions, nevertheless when tested for microbiological activity all the compounds were found practically inactive in respect to the parent doxycycline; only $\mathbf{2} \mathbf{f}$ of course, maintains a good activity as the other derivatives of its type.

According to our present results it is possible to confirm that not only the carbonyl but all the carboxamido group at C-2 position is very important for the antibiotic activity and any modification which involves more than one hydrogen on it, leads to gaps in the antimicrobial spectrum. The diketoamide moiety in the A ring is involved in a very unusual ketoenol tautomerism with very strong hydrogen bond. This fact is also evident in the NMR spectrum of doxycycline in which the two NH amide protons are quite different in the chemical shift ( $\delta 8.1$ and $8.8 \mathrm{DMSO}-\mathrm{d}_{6}$ ). The chemical modifications carried out on compounds $\mathbf{2 b}, \mathbf{c}, \mathbf{d}$, e displace dramatically the extensive electron delocalization of this system (causing the lack of antibiotic activity) also in the case of $\mathbf{2} \mathbf{d}$ as monitored by the NMR spectrum of this compound in which the $\mathrm{NH}_{2}$ amide signal is a single peak at 9.2 indicating an electronic equivalence for the two protons.

\section{Conclusions}

Positions 5, 6 and also 2 in lesser extent, are known as not very critical for antibiotic activity (of course with marked differences between positions 5 and 6 which can tolerate even drastic modifications without significantly loosing antimicrobial potency and position 2 where a carbonyl group is said to be the minimum requirement for an antimicrobial action of no practical interest). The synthesis of new tetracycline analogs modified at these positions allows to confirm, and partially to extend, what is presently known about structure-activity relationships in the tetracycline field.

All the described compounds were practically inactive against both Gram-positive and Gram-negative bacteria. It is therefore possible to conclude that at $\mathrm{C}-2$ the presence of an unchanged carboxamido group is very important and critical for maintenance of a significant and practically useful, antimicrobial action, and the hybridization of the 5 carbon atom cannot be changed.

More surprising was the poor activity of the 6-hydroxymethyl derivative (3b) (in every case the most active of the series studied), perhaps imputable to the unnatural stereochemistry at C-6.

\section{Experimental}

The melting points were uncorrected. ${ }^{1} \mathrm{H}$ NMR spectra were obtained at $60 \mathrm{MHz}$ on a PerkinElmer R24-B spectrometer. Chemical shifts $(\delta)$ are reported as parts per million from tetramethylsilane. Infrared and ultraviolet spectra were recorded using a Perkin-Elmer $157 \mathrm{G}$ and 550 spectrophotometer, respectively. Thin-layer chromatography (tlc) was carried out on Merck silica gel plates, sprayed with a $0.5 \%$ EDTA solution and dried at $110^{\circ} \mathrm{C}$ eluted with $\mathrm{Me}_{2} \mathrm{CO}-\mathrm{EtOAc}-\mathrm{H}_{2} \mathrm{O}(80: 35: 15)$. Column chromatographies were performed on silica gel (Merck, 60 200 mesh) pretreated with EDTA at pH 7.2 and dried at $110^{\circ} \mathrm{C}$ (eluted with $\mathrm{Me}_{2} \mathrm{CO}-$ EtOAc $-\mathrm{H}_{2} \mathrm{O}(80: 35: 15)$ ) or on cellulose (eluted with $n-\mathrm{BuOH}$

* The reaction was carried out as in Reference 12). 
saturated with $\mathrm{H}_{2} \mathrm{O}$ ).

\section{5-Deoxy-5-oxodoxycycline (2a)}

A solution of doxycycline $(8.8 \mathrm{~g}, 19.7$ mmoles $)$ in DMSO $(40 \mathrm{ml})$ and $\mathrm{Ac}_{2} \mathrm{O}(42 \mathrm{ml})$ was stirred for 20 hours at room temperature, then was diluted with water and extracted with $n$ - $\mathrm{BuOH}(3 \times 200 \mathrm{ml})$. The organic phase was dried on $\mathrm{Na}_{2} \mathrm{SO}_{4}$ and concentrated under vacuum. The residuum, diluted with $\mathrm{MeOH}(\sim 10 \mathrm{ml})$, was precipitated with $\mathrm{Et}_{2} \mathrm{O}$. Purification on column chromatography (silica gel) of the crude yellow product ( $6 \mathrm{~g}, 68 \%$ yield) gave the pure 5-deoxy-5-oxodoxycycline (2a), m.p. 193 $195^{\circ} \mathrm{C}$; UV $\lambda_{\max }^{\mathrm{MeOH}} 275 \mathrm{~nm}(\varepsilon=18,000), 365$ (14,500); IR (nujol): 3300, 1740, 1660, $1620 \mathrm{~cm}^{-1}$; NMR $\left(\right.$ DMSO-d $\left._{6}\right): \delta 1.2\left(3 \mathrm{H}, \mathrm{d}, \mathrm{CH}_{3}\right), 2.4\left(7 \mathrm{H}, \mathrm{m}, \mathrm{N}\left(\mathrm{CH}_{8}\right)_{2}, \mathrm{C}_{8}-\mathrm{H}\right), 2.8\left(2 \mathrm{H}, \mathrm{m}, \mathrm{C}_{4 \mathrm{a}}-\mathrm{H}, \mathrm{C}_{5 \mathrm{a}}-\mathrm{H}\right), 3.3\left(1 \mathrm{H}, \mathrm{d}, \mathrm{C}_{4}-\right.$ $\mathrm{H}), 6.5 \sim 7.4\left(3 \mathrm{H}, \mathrm{m}\right.$, aromatics), $8.1 \sim 8.8\left(2 \mathrm{H}, \mathrm{d}, \mathrm{CONH}_{2}\right)$. Compound (3a), a product with very similar analytical data, was obtained starting from 3 in similar way.

2-Ethoxycarbonyl-2-decarboxamidodoxycycline (2b)

A solution of 2-cyano-2-decarboxamidodoxycycline (5 g, 11.7 mmoles) in EtOH (150 ml) was saturated with anhydrous $\mathrm{HCl}$ and refluxed for 36 hours. The solvent was then evaporated and the residue diluted with water, neutralized to $\mathrm{pH} 4$ and extracted in $n$-BuOH $(3 \times 100 \mathrm{ml})$. Usual work up and purification by column chromatography (silica gel) gave $2 \mathbf{b}\left(1 \mathrm{~g}, 18 \%\right.$ yield): m.p. $188 \sim 190^{\circ} \mathrm{C}$; IR (nujol) $1730,1620 \mathrm{~cm}^{-1}$ : UV $\lambda_{\max }^{\mathrm{MeOH}} 265 \mathrm{~nm}(\varepsilon=17,700), 360(\varepsilon=13,500) ; \mathrm{NMR}\left(\mathrm{CF}_{3} \mathrm{COOH}\right): \delta 1.1(3 \mathrm{H}$, d, $\left.\mathrm{CH}_{3}-\mathrm{C}_{6}\right), 1.6\left(3 \mathrm{H}, \mathrm{t}, \mathrm{CH}_{3}-\mathrm{CH}_{2}-\mathrm{O}\right), 2.7\left(6 \mathrm{H}, \mathrm{s}, \mathrm{N}\left(\mathrm{CH}_{3}\right)_{2}\right), 3.1 \sim 3.6\left(3 \mathrm{H}, \mathrm{m}, \mathrm{C}_{8}-\mathrm{H}, \mathrm{C}_{5 \mathrm{a}}-\mathrm{H}, \mathrm{C}_{4 \mathrm{a}}-\mathrm{H}\right)$, $3.7 \sim 4.1\left(3 \mathrm{H}, \mathrm{m}, \mathrm{C}_{4}-\mathrm{H}, \mathrm{CH}_{2}\right), 5.0\left(1 \mathrm{H}, \mathrm{d}, \mathrm{C}_{5}-\mathrm{H}\right), 6.2 \sim 7.0(3 \mathrm{H}, \mathrm{m}$, aromatics $) ;[\alpha]_{\mathrm{D}}+35.3^{\circ}(c 0.02, \mathrm{MeOH})$.

2-Cyano-2-decarboxamidodoxycycline (2c)

A solution of doxycycline hydrochloride $(50 \mathrm{~g}, 0.1$ moles $)$ and $\mathrm{N}, \mathrm{N}$-dicyclohexylcarbodiimide (DCC) $(50 \mathrm{~g}, 0.24$ moles) in $\mathrm{MeOH}(500 \mathrm{ml})$ was stirred for 6 hours at room temperature. The resulting solution was concentrated under vacuum and the dicyclohexylurea was filtered off. The clear solution was evaporated to give a crude product which was suspended in $\mathrm{CHCl}_{3}-\mathrm{Et}_{2} \mathrm{O}(2: 1)$ and filtered. The yellow product $(41 \mathrm{~g})$ was crystallized from $n$-BuOH obtaining $23 \mathrm{~g}(51 \%$ yield) of 2 c. m.p. $226 \sim$ $228^{\circ} \mathrm{C}$, IR (nujol) 2200, $1620 \mathrm{~cm}^{-1}$; UV $\lambda_{\max }^{\mathrm{MeOH}} 270 \mathrm{~nm}(\varepsilon=18,100), 360(13,000)[\alpha]_{\mathrm{D}}-74.01^{\circ}(c 0.05$, $\mathrm{MeOH})$.

2-Thiocarboxamide-2-decarboxamidodoxycycline (2d)

A suspension of doxycycline hydrochloride ( $5 \mathrm{~g}, 10.4$ mmoles $)$ and $\mathrm{P}_{2} \mathrm{~S}_{5}(2.87 \mathrm{~g}, 12.5$ mmoles $)$ in dioxane $(100 \mathrm{ml})$ was stirred for 18 hours at $22^{\circ} \mathrm{C}$. The resulting yellow solution was poured in cooled water $\left(5^{\circ} \mathrm{C}\right)$, the $\mathrm{pH}$ adjusted to 4 , filtered and the clear solution extracted with $n$ - $\mathrm{BuOH}(3 \times 200 \mathrm{ml})$. The organic layer, dried on $\mathrm{Na}_{2} \mathrm{SO}_{4}$, was evaporated in vacuo and the residue purified on column chromatography (silica gel). The yellow product was crystallized from $\mathrm{MeOH}(2.8 \mathrm{~g}$, yield $58.3 \%)$ : m.p. 222 225 ${ }^{\circ} \mathrm{C}$; IR (nujol) $3340,1620 \mathrm{~cm}^{-1}$; UV $\lambda_{\max }^{\mathrm{MeOH}} 270 \mathrm{~nm}(\varepsilon=18,000), 360(14,000)$; NMR $\left(\mathrm{CF}_{3^{-}}\right.$ $\mathrm{COOH}): \delta 1.1\left(3 \mathrm{H}, \mathrm{d}, \mathrm{CH}_{3}-\mathrm{C}_{6}\right), 2.7\left(6 \mathrm{H}, \mathrm{s}, \mathrm{N}\left(\mathrm{CH}_{3}\right)_{2}\right), 3.1 \sim 3.6\left(3 \mathrm{H}, \mathrm{m}, \mathrm{C}_{8}-\mathrm{H}, \mathrm{C}_{5 \mathrm{a}}-\mathrm{H}, \mathrm{C}_{4 \mathrm{a}}-\mathrm{H}\right), 3.9(1 \mathrm{H}$, d, $\left.\mathrm{C}_{4}-\mathrm{H}\right), 4.8\left(1 \mathrm{H}, \mathrm{d}, \mathrm{C}_{5}-\mathrm{H}\right), 6.2 \sim 7.0\left(3 \mathrm{H}, \mathrm{m}\right.$, aromatics), $9.1\left(2 \mathrm{H}, \mathrm{s} \mathrm{CSNH}_{2}\right) ;[\alpha]_{\mathrm{D}}-180.33^{\circ}(c 0.1$, $\mathrm{MeOH})$;

$$
\begin{array}{ll}
\text { Anal. Calcd for } \mathrm{C}_{22} \mathrm{H}_{23} \mathrm{O}_{7} \mathrm{~N}_{2} \mathrm{~S}: & \mathrm{C}, 57.5 ; \mathrm{H}, 5.04 ; \mathrm{N}, 6.1 ; \mathrm{S}, 6.98 \\
\text { Found: } & \text { C, } 56.8 ; \mathrm{H}, 5.0 ; \mathrm{N}, 5.9 ; \mathrm{S}, 6.62
\end{array}
$$

2-Aminomethyl-2-decarboxamidodoxycycline (2e)

A solution of $2 \mathrm{~d}(2.0 \mathrm{~g}, 4.3 \mathrm{mmoles})$ in $\mathrm{EtOH}(40 \mathrm{ml})$ was stirred under $\mathrm{H}_{2}$ at $22^{\circ} \mathrm{C}$ with freshly prepared RANEX-nickel $(10 \mathrm{~g})$ until disappearance of $\mathbf{2} \mathrm{d}$ (tlc monitoring). The catalyst was filtered off, the resulting solution concentrated in vacuo and the crude product crystallized from $\mathrm{MeOH}-\mathrm{Et}_{2} \mathrm{O}$ to give 2e $\left(1.6\right.$ g; yield $86 \%$ ): m.p. $212^{\circ} \mathrm{C}$ (dec.); IR (nujol) $3340,1620 \mathrm{~cm}^{-1}$; UV $\lambda \underset{\max }{\mathrm{MeOH}} 225 \mathrm{~nm}(\varepsilon=16,200$ ), $360(12,000)$.

Anal. Calcd for $\mathrm{C}_{22} \mathrm{H}_{25} \mathrm{O}_{7} \mathrm{~N}_{2}:$ C, $61.5 ; \mathrm{H}, 5.9 ; \mathrm{N}, 6.52$.

$$
\text { Found: } \quad \mathrm{C}, 60.6 ; \mathrm{H}, 5.6 ; \mathrm{N}, 6.14 \text {. }
$$

6-Demethyl-6-hydroxymethyloxytetracycline (3b)

To a solution of methacycline hydrochloride $(10 \mathrm{~g}, 22.5 \mathrm{mmoles})$ in $\mathrm{H}_{2} \mathrm{O}(280 \mathrm{ml})$ and $\mathrm{MeOH}$ $(150 \mathrm{ml})$ was added $\mathrm{KClO}_{3}(5.5 \mathrm{~g}, 45$ mmoles $)$ and a catalytic amount of $\mathrm{OsO}_{4}$. The solution was 
stirred for 24 hours at room temperature then $\mathrm{MeOH}$ saturated with $\mathrm{H}_{2} \mathrm{~S}(250 \mathrm{ml})$ was added. The $\mathrm{OsS}_{2}$ was filtered off and the $\mathrm{MeOH}$ concentrated under vacuum; the resulting aqueous solution, neutralized with $0.1 \mathrm{~N} \mathrm{NaOH}$ and diluted with brine, was extracted with $n$-BuOH from which, after drying and concentration under vacuum, a yellow product was obtained $(9.8 \mathrm{~g})$. A sample $(0.5 \mathrm{~g})$ was purified on column chromatography (cellulose microcrystalline) obtaining $3 \mathbf{b}$ analytically pure $(0.3 \mathrm{~g})$ : m.p. $250^{\circ} \mathrm{C}$; IR (nujol): $3350,1660,1620 \mathrm{~cm}^{-1}$; UV $\lambda_{\max }^{\mathrm{MeOH}} 270 \mathrm{~nm}(\varepsilon=18,500), 372(16,000)$; NMR (DMSO$\left.\mathrm{d}_{6}\right)$ : ò $2.8\left(8 \mathrm{H}, \mathrm{m}, \mathrm{N}\left(\mathrm{CH}_{3}\right)_{2}, \mathrm{C}_{4 \mathrm{a}}-\mathrm{H}, \mathrm{C}_{5 \mathrm{a}}-\mathrm{H}\right), 3.4\left(2 \mathrm{H}, \mathrm{s}, \mathrm{CH}_{2} \mathrm{OH}\right), 3.7\left(1 \mathrm{H}, \mathrm{d}, \mathrm{C}_{4}-\mathrm{H}\right), 6.8 \sim 7.7(3 \mathrm{H}, \mathrm{m}$, aromatics), $9.0 \sim 9.7\left(2 \mathrm{H}, \mathrm{d}, \mathrm{CONH}_{2}\right)$.

Anal. Calcd for $\mathrm{C}_{22} \mathrm{H}_{24} \mathrm{O}_{10} \mathrm{~N}_{2}$ : C, $55.46 ; \mathrm{H}, 5.08 ; \mathrm{N}, 5.88$.

Found: $\quad$ C, $55.02 ; \mathrm{H}, 4.92 ; \mathrm{N}, 5.71$.

6-Hydroxyanhydrooxytetracycline (4)

To a solution of $\mathbf{2 b}(0.5 \mathrm{~g}, 0.9$ mmoles $)$ in $\mathrm{MeOH}-\mathrm{H}_{2} \mathrm{O}(1: 1,15 \mathrm{ml})$, periodic acid $(0.2 \mathrm{~g}, 0.9$ mmoles) was added under stirring. The reaction was stirred for 3 hours, then poured in water, the $\mathrm{pH}$ adjusted to 6.5 and the compound extracted in $n$ - $\mathrm{BuOH}(3 \times 100 \mathrm{ml})$. The organic layer dried on $\mathrm{Na}_{2} \mathrm{SO}_{4}$ and evaporated in vacuo. The crude yellow-orange product $(0.32 \mathrm{~g}, 80 \%$ yields $)$ was crystallized from $\mathrm{MeOH}-\mathrm{Et}_{2} \mathrm{O}$ : m.p. $187 \sim 190^{\circ} \mathrm{C}$; IR (nujol) $3500 \sim 3300,1730,1660,1620 \mathrm{~cm}^{-1}$; UV $\lambda_{\max }^{\mathrm{MeOH}} 274 \mathrm{~mm}$ $(\varepsilon=16,000), 471(8,000)$.

Anal. Calcd for $\mathrm{C}_{21} \mathrm{H}_{18} \mathrm{O}_{9} \mathrm{~N}_{2}$ : Found:

$\mathrm{C}, 57.01 ; \mathrm{H}, 4.1 ; \mathrm{N}, 6.33$.

C, $57.18 ; \mathrm{H}, 4.0 ; \mathrm{N}, 6.28$.

\section{Acknowledgement}

The authors wish to express their thanks to Mr. Simeoni and Mr. Rosato for their technical assistance in this investigation.

\section{References}

1) Blackwood, R. K. \& A. R. English: Structure-Activity Relationships in the Tetracycline Series. In "Structure-Activity Relationships among Semi-Synthetic Antibiotics" Ed. D. Perlman, Academic Press, N. Y., pp. 397 426, 1977

2) Barreti, G. C.: Synthesis of tetracycline analogs. J. Pharm. Sci. 52: 309 330, 1963

3) Stephens, C. R.: U.S. Patent 3,028,409 (Chas Pfizer and Co.): Chem. Abst. 57: 9769 g (1962)

4) Korst, J. J.: DOS 2065149 (1972), Pfizer Inc.

5) KoRst, J. J.: DOS 2049941 (1972), Pfizer Inc.

6) Miller, M. W. \& F. A. Hochstein: Isolation and characterisation of two new tetracycline antibiotics. J. Org. Chem. 27: 2525 2528, 1962 and Hochstein, F. A.; M. Schach von Wittenau, F. W. Tanner, Jr. \& K. Murai: 2-Acetyl-2-decarboxamidooxytetracycline. J. Am. Chem. Soc. 82: 5934 5937, 1960

7) Some of these compounds have been presented as a preliminary communication: BrANDT, A.; G. B. Corsi, G. PASCUCCI \& U. VAlCAvI: Synthesis of some novel C-2 derivatives in the tetracycline series. Tetrahedron Lett. 1979: 2701 2704, 1979

8) Blackwood, R. K.; J. J. Beereboom, H. H. Rennhard, M. Schach von Wittenau \& C. R. Stephens: 6-Methylenetetracyclines: III. Preparation and properties. J. Am. Chem. Soc. 85: 3943 3953, 1963

9) Stephen, C. R.; J. J. Beereboom, H. H. Rennhard, P. N. Gordon, K. Murai, R. Blackwood \& M. S. von Wittenau: 6-Deoxytetracyclines: IV. Preparation, C-6 stereochemistry and reactions. J. Am. Chem. Soc. 85: 2643 2652, 1963

10) von Wittenau, M. S.; R. K. Blackwood, L. H. Conover, R. H. Glauert \& R. B. Woodward: The stereochemistry at C-5 in oxytetracycline. J. Am. Chem. Soc. 87: 134 135, 1965

11) See, for example, the UV spectra of 1-hydroxy-2-acetonapthone and the 1,4-dihydroxy-2-acetonaphtone in: Organic Electronic Spectral Data, Vol. 1, Interscience Pub. Inc., N.Y., pag. 446 and 448.

12) Gottstein, W. J.; W. F. Minor \& L. C. Cheney: Carboxamido derivatives of the tetracyclines. J. Am. Chem. Soc. 81: 1198 1201, 1959 